УДК

DOI https://doi.org/10.31723/2524-0447-2021-32-2-2

\author{
Наталія Володимирівна Остроухова \\ ORCID: 0000-0002-4266-1283
}

кандидат мистецтвознавства, доцент, доцент кафедри загального та спеціалізованого фортепіано Одеської національної музичної академії імені А. В. Нежданової Pchela45@i.ua

\title{
РІКАРДО БОНІЧОЛІ - КОМПОЗИТОР І ДИРИГЕНТ ОДЕСЬКОЇ ІТАЛІЙСЬКОЇ ОПЕРИ
}

Мета роботи - виявлення біографічних даних та творчого доробку Рікардо Бонічолі - композитора і диригента італійської опери в Одесі в 1887-1889 роках. Досі не вдалося знайти його біографiї, відомості про иього мития дуже розрізненні. Але як біографічні словники, так i статті європейських і американських вчених наголошують на його художніх досягненнях. Методологія дослідження трунтується на історико-культурологічному, теоретичному $і$ жанрово-стильовому аналізі діяльності Рікардо Бонічолі як композитора та диригента Одеської опери, його внеску в ї̈ розвиток. Наукова новизна статті полягає у висвітленні ролі особистості Рікардо Бонічолі як диригента та композитора європейського масштабу. Йому випала відповідальність за вибір художнього напряму подальшого розвитку театру, як першому капельмейстеру нового унікального за красою, якостями архітектури й акустики оперного театру в Одесі. Висновки. Виявлено невідомі раніше відомості з біографії Рікардо Бонічолі, який два роки очолював італійську оперу антрепризи I. Черепеннікова (1887-1889 роки). Рікардо Бонічолі помітно підняв рівень виконавської майстерності місцевого оперного оркестру $i$ хорів. Репертуар збагатився першою постановкою в Одесі опери Р. Вагнера «Лоенгрін». Виконувалися опери Дж. Россіні, Г. Доніцетті, Дж. Верді, Дж. Мейєрбера, Ш. Гуно, А. Понк'єллі, A. Бойто тощо. Після виконання камерних творів диригента, у яких брав участь Микола Лисенко, зазначалося, що Р. Бонічолі належить до нового напряму інструментальних композиторів Італії. Виявлено також творче оточення мития в часи створення музики до трьох балетів, які були поставлені в Італії, а також його внесок у розвиток музичної історії Греції й Аргентини як автора опер про історичні постаті цих країн.

Ключові слова: Одеська італійська опера, особистість диригента i композитора Рікардо Бонічолі, виконавська майстерність європейського масштабу, оновлення та розвиток репертуару.

(C) Остроухова Н. B., 2021 
Ostroukhova Natalia Volodimirivna, Doctor of Art History, Associate Professor, Associate Professor at the Department of General and Specialized Piano of the Odessa National A. V. Nezhdanova Academy of Music

Ricardo Bonicioli - the composer and conductor of the Odessa Italien opera

Research objective. The purpose of the work is to reveal the biographical data and creative work of Ricardo Bonicioli - a composer and conductor of the Italian Opera in Odessa in 1887-1889. So far it has been impossible to find his full life biography, because the information about this artist is very fragmented. But both biographical dictionaries and articles by European and American scholars emphasize his artistic achievements. The methodology is based on the historical-cultural, theoretical and genre-style analysis of Ricardo Bonicioli's activity as a composer and conductor of the Odessa Opera and his contribution to its development. The scientific novelty of the article is to highlight the role of Ricardo Bonicioli as a conductor and composer of European scale. He was responsible for choosing the artistic direction of the further development of the theater as the first conductor of the new unique in its beauty, quality of architecture and acoustics opera house in Odessa. Conclusions. Previously unknown information on the biography of Ricardo Bonicoli, who for two years directed the Italian opera of the enterprise of I. Cherepennikov (1887-1889), was revealed. Ricardo Bonicoli has significantly raised the level of performance of the local opera orchestra and choirs. The repertoire was enriched by the first staging in Odessa of R. Wagner's opera "Lohengrin”. Operas by G. Rossini, G. Donizetti, J. Verdi, J. Meyerbeer, S. Gounod, A. Ponquelli, A. Boyto, etc. were performed. After performance of the chamber works of the conductor, in which Mykola Lysenko took part, it was noted that $R$. Bonicoli belongs to a new direction of instrumental composers in Italy. The creative environment of the artist during the creation of music for three ballets, which were staged in Italy, as well as his contribution to the development of the musical history of Greece and Argentina as the author of operas about historical figures of these countries, was also revealed.

Key words: Odessa Italian Opera, personality of conductor and composer Ricardo Bonicioli, performing skills of European scale, renewal and development of repertoire.

Актуальність теми дослідження полягає в більш детальному розкритті творчих індивідуальностей музикантів, які працювали в Одеській опері.

1 жовтня 1887 р. відбулося урочисте відкриття Одеського міського театру, який (що дуже важливо) будувався для оперних вистав. Иого розміри значно перевищували необхідні розміри для драми, але підходили для опери. Досконале архітектурне створення дало нове життя музичним виставам, операм, постановка яких у цей час вимагала вже не «концерту в костюмах», а вистави, у якій музика, режисура та сценографія становили б єдине ціле. 
Першим антрепренером Одеської опери протягом двох років був Іван Іванович Черепенніков, член думи і редактор газети «Одесские новости» (рос.). У перший рік він зобов'язався утримувати російську драму і в наступні зимові місяці оперу; у другому році - оперу і драму водночас. У складі трупи було 52 солісти опери, 34 драматичних артистів, 52 артисти хору. Контракт з оркестром із 52 музикантів був укладений на цілий рік.

Антрепренер формував склад італійської оперної трупи, до якої увійшли: драматичне сопрано Надія Буличова, уродженка Нижнього Новгороду, співала у столицях, в Італії й Америці, звідки і запрошена; меццо-сопрано італійка Олімпія Гверчіа з Неаполя; 1-й тенор di forza іспанець Гаетано Ортізі, який співав у Варшаві і Мадриді; 1-й тенор Орест Капелетті; 1-й бас Гаетано Монті - колосальний за голосом і ростом, з Італії; баритон Поцці або Броджі; бас одесит Віктор Донаті, який виконував у Мілані Мефістофеля у «Фаусті»; молодий баритон Ернест Міотті. Для керівництва оперними спектаклями був запрошений італійський диригент Буонічіолі [19, с. 3] (Рікардо Бонічолі).

Мета дослідження. Виявлення біографічних даних та творчого доробку Рікардо Бонічолі - композитора і диригента італійської опери в Одесі в 1887-1889 рр. На жаль, біографічні дані про Рікардо Бонічолі нечисленні. У словниках про нього сказано буквально таке: Bonicioli, Ricardo (Vatername Frıhmann) 19. Mai 1853 Zara † 17. Mдrz 1933 Como. Bьhnenwerk Marco Botzaris Oper (Madrid, 1884), Don Juan de Garay Oper (Buenos Aires, 1900) [2]. Бонічолі, Рікардо (по батькові Фрюман) народився 19 травня 1853 р. у місті Зара, помер 17 березня 1933 р. в місті Комо. Автор опери «Марко Боцарі» (Мадрид, 1884 р.) та «Дон Хуан де Гарай» (Буенос-Айрес, 1900 р.).

Наукова новизна. Як з'ясувалося, творча біографія диригента і композитора Рікардо Бонічолі багато в чому була пов'язана із Грецією й Аргентиною. Нашу увагу привернула стаття Ekaterini Romanou «Італійські музиканти у Греції в XIX ст.i» [12, с. 43-55], з якої дізнаємося цікаві факти про Р. Бонічолі. У XIX ст. на Іонічних островах, зокрема на найбільшому з них - о. Корфу, що ніколи не перебував під владою Османської імперії, виникла музична культура, дуже схожа на музику Неаполя. Філармонійним товариством 
проводилися оперні сезони і концерти, змодельовані з Неаполітанської консерваторії. Серед диригентів, викладачів і оркестрантів Філармонійного товариства було багато оркестрових музикантів з італійських оперних груп, які вирішили залишитися на острові. Вони виступали, чергуючись із грецькими музикантами. Директором групи в 1843 р. став Нікола Олів’єрі - перша флейта та флейта-пікколо з оперної групи, яка неодноразово виступала в театрі Сан-Джакомо з 1841 p. Потім його змінив Джованні Рагаццьолі. Серед директорів цих труп знаходимо і Рікардо Бонічолі.

Музиканти духового оркестру залишили значну кількість транскрипцій і оригінальні композиції, деякі з яких, що згадують події або постаті новітньої грецької історії, стали великими хітами. Так було із драматичною оперою Р. Бонічолі «Марко Боццарі». Головний герой цієї опери був реальною історичною особою, грецьким воєначальником, героєм Визвольної війни Греції 1821-1829 рр. [15]. Опера була вперше виконана філармонійним товариством о. Корфу 9 лютого 1883 р.

Виклад основного матеріалу. 31887 по 1889 pp. Р. Бонічолі був головним диригентом Одеської опери. Зрозуміло, що від нього багато в чому залежала репертуарна політика театру. Можна припустити, що склад солістів із драматичними голосами для відкриття театру був дібраний не випадково, а в розрахунку на постановку таких вистав, як «Сила долі» Дж. Верді, «Мефістофель» А. Бойто, «Лоенгрін» Р. Вагнера тощо, на що звертали увагу не тільки в Одесі, але і в Італії.

Перший сезон тривав два місяці (із 17 грудня 1887 р. по 20 лютого 1888 р.). Після першої вистави на новій сцені опери Дж. Мейєрбера «Гугеноти» - «Новороссийский телеграф» писав: «<..> У міському театрі відкрито сезон італійської опери з повним успіхом. <..> Сміливо стверджуємо, що такої постановки Одеса ще не бачила. Лаври пожинали особливо пані Буличова, яку публіка прийняла захоплено. Мали повний успіх також тенор Капелетті, г-жа Гверчіа і бас Монті. Диригент Бонічолі довів, що може зробити досвідчений шеф оркестру навіть із нашими місцевими силами» [17, с. 3].

Завдяки професійній критиці журналіста і музиканта I. Кузьмінського й сьогодні можна відчути художню атмосферу того часу. У відгуках на вистави відчувається, як майстерність диригента Р. Бонічолі підкреслює індивідуальні риси кожного композитора. Так, після опери «Фауст» критик 
пише: «Гуно, переважно, співак любові тихої, ідилічної. Сильні драматичні рухи не дуже часто йому вдаються, зате ніхто не зобразить із такою грацією і теплотою ліричний настрій. Тому 3-я дія «Фаусту» назавжди залишиться найкращим пам'ятником музичної творчості. <..> Буличова грає Маргариту скромно, просто і природно. Гуно ближче ій, ніж Мейєрбер $<\ldots>$ » [17, с. 3]. Наступною постановкою була опера «Трубадур». Критик убачає в цьому «поворот у характері вибору опер на сцені Міського театру». Він називає цю оперу «застарілим продуктом колишньої манери Верді», не розуміючи, «чому ця опера ще тримається в репертуарі великих і провінційних сцен?» [14, с. 1]. В «Африканці» Дж. Мейєрбера відзначена «маса гармонійного багатства і розмаїтість ритму», які виявлено гарними виконавцями: Буличова (Селика), Ортізі (Васко да Гама), Поцці-Біязі (Нелуско), Монті (Інквізитор), Донаті (Дон Педро), Горе-Ровере (Інеса). І. Кузьмінський виділяє оперу «Джоконда», яка виконувалася 17 лютого в бенефіс Н. Буличової. Він називає Понкієллі одним із «сучасних італійських новаторів, які усвідомили необхідність витягнути італійську драматичну музику із традиційної колії. Наприклад, сцена побачення Лаури і Джоконди задумана красиво й оригінально. Понкієллі навіть дозволив собі закінчити 1-й акт тихою покійною музикою, без крикливого фіналу» [14].

19 лютого 1888 р. в бенефіс диригента Рікардо Бонічолі виконувалася симфонічна поема «Аркадія» у 4-х частинах під управлінням автора.

Італійська опера I. Черепеннікова відразу завоювала загальні симпатії і настільки затьмарила собою драму, що на другий сезон - з 1 жовтня 1888 р. по 22 лютого 1889 р., антрепренер з дозволу міста відмовився від драми і залишив тільки оперу. Були запрошені нові виконавці: сопрано Ауреліо Катанео і Франческа Прево, знаменитий іспанський тенор А. Арамбуро, баритони Н. Цардо і М. Поллі, бас А. Россі.

Репертуар поповнився операми Дж. Верді («Бал-маскарад», «Ріголетто», «Травіата», «Сила долі» й «Ернані»), Ж. Бізе («Кармен»), Р. Вагнера («Лоенгрін»), Г. Доніцетті («Лукреція Борджа» та «Лючія ді Ламмермур»), А. Бойто («Мефістофель»), Дж. Россіні («Севільський цирульник»).

«Одесские новости» писали про італійську оперу I. Черепеннікова: «Другий оперний сезон почався 1 жовтня і досі тримається суто на операх Верді. 3 «Аїди» почався сезон 
і так весь час. Це занадто ризиковано. Слабкі збори на «Травіаті» і «Трубадурі» і вільні місця на «Ернані». Хочеться хоч на час позбутися від цих убитих мотивів, фальшивих сценічних положень і безглуздих лібрето. Хочеться різноманітності і новизни» $[18$, с. 2].

Мабуть, антрепренер дослухався критичних зауважень. 22 лютого 1889 р. Р. Бонічолі здійснив постановку опери «Мефістофель», яка, на думку критика W., уважається кращою оперою сучасного італійського композитора і поета Арріго Бойто (в Одесі опера вперше виконувалася 10 листопада 1885 р.). У цьому спектаклі особливий успіх мала Олімпія Гверчіа (Гуерча) (Маргарита). Підкорювали іiі сильний голос і красива артистична зовнішність. Міланська «Театральна газета» опублікувала вірші одеського автора, присвячені «блискучому» виконанню А. Россі й інших артистів [16, с. 36-37]. 18 лютого 1889 р. диригент Рікардо Бонічолі вперше в Одесі поставив оперу Р. Вагнера «Лоенгрін», і ця подія теж викликала жваві обговорення [1, с. 4].

Справи I. Черепеннікова завдяки італійській опері були блискучі. Після закінчення зимового сезону артистів було запрошено до Києва. Гастролі на сцені театру «Соловцов» продовжувалися із 27 лютого по 1 квітня 1889 р. Зазначалося, що диригент Р. Бонічолі «помітно підняв рівень виконавської майстерності місцевого оперного оркестру і хорів». Він справив сильне враження на публіку, провів понад 20 вистав як головний диригент і концертмейстер. Виконувалися «Фаворитка» та «Лючія ді Ламмермур» Г. Доніцетті, «Севільський цирульник» Дж. Россіні, «Аїда», «Травіата», «Бал-маскарад», «Трубадур» Дж. Верді, «Африканка» та «Гугеноти» Дж. Мейєрбера, «Фауст» Ш. Гуно, «Кармен» Ж. Бізе.

На гастролях виконувалися також твори Р. Бонічолі. 29 березня, у свій бенефіс, він продемонстрував обробку прелюдії Й.С. Баха для струнного оркестру, фортепіано й арфи, «Менует» для струнного оркестру. Зазначалося, що він належить до «нового напряму інструментальних композиторів Італії. 3 анонсу газети «Киевлянин» дізнаємося, що 16 квітня 1889 р. в залі купецького зібрання (нині Київська філармонія) відбудеться концерт диригента-концертмейстера італійської опери Рікардо Бонічіолі «при благосклонном участии» пані Франчески Прево та пп. Лисенка, Сікарда, П'ятигоровича, фон Мулерта, Шутмана, Рогового та великого оркестру 
[20, с. 354]. «Жвавий інтерес викликала «Далматська серенада» Р. Бонічолі для двох скрипок, флейти і фортепіано, у виконанні якої брав участь як піаніст український композитор М. Лисенко разом із місцевими віртуозами-інструменталістами М. Сікардом, А. Шутманом і Роговичем, і «Менует» для двох скрипок, альта і віолончелі. Виконувалися також його симфонічні поеми «Аркадія» й «Останні хвилини Бетховена», у яких, за оцінкою критиків, він «виявив себе як глибокий мислитель»; а також велика вокальна п'єса за участі примадонни опери Франчески Прево в супроводі оркестру та романс «Сльози матері» [16, с. 36-37]. Продовжуючи пошуки біографічних даних Рікардо Бонічолі, ми знаходимо відомості про музиканта у Валенсії, у сезоні 1890/1891 pp., де він керував італійською трупою, яка виконувала оперу Ж. Бізе «Шукачі перлів» [9].

У 1893 р. Рікардо Бонічолі був запрошений до Афін друзями музики Асоціації з метою створення оркестру. На той час багато інших італійців і греків з Іонічних островів вже оселились в Афінах. Культурний клімат тут був зовсім іншим, ніж на Іонічних островах. Освіта здебільшого була пов'язана із церквою, установою, що об'єднувала греків протягом чотирьох століть османського ярма і підтримувала їхню національну свідомість. На думку дослідників, давньогрецька музика була переважно монодійною. Оригінальна нотація монодійної поезії вважалась грецькою національною традицією аж до початку XX ст. Мелодія записувалася за допомогою грецьких і фінікійських букв, причому існували різні позначення нот для вокальної та інструментальної партій. Над нотами також писалися ритмічні позначення [21]. У XIX ст. почалося перетворення грецької музичної традиції відповідно до моделі західної міської культури. Гармонія, західна нотація і західні інструменти були введені разом із відповідною практикою. У цій трансформації італійські музиканти відіграли центральну роль.

Виходячи із хронології постановок творів Р. Бонічолі, можна припустити, що в 1880-х та в 1890-х рр. композитор працював в Італії й Іспанії (за винятком одеського періоду). Так, восени 1881 р. на сцені міланського театру Даль Верме виконувався великий балет «Надя» із семи частин та восьми картин на музику Рікардо Бонічолі. Хореограф Джованні Буттеріні (Буттуріні) [10]. "Nadya : ballo grande in sette parti ed otto 
quadri : rappresentato sulle scene del Teatro dal Verme la stagione d'autunno 1881 [3]. Coreografo Giovanni Butturini; musica dei maestri Bonicioli”. Далі: 1884 p. - постановка в Мадриді його опери «Марко Боцарі». Цього ж року в Мадриді гастролювала Надія Буличова. Восени 1888 р. в театрі даль Верме відбулася прем'єра балету «Акробат» на музику Р. Бонічолі. Жанр позначений як напівсерйозний танець із прологом у шести картинах. Хореографія Джованні Понья. Антреприза Луїджі Чезарі та $\mathrm{C}^{\circ}$. "Il saltimbanco : ballo semiserio in un prologo e sei quadri del coreografo Giovanni Pogna. Musica del maestro Riccardo Boniccioli : Teatro dal Verme autunno1888. Impreswa Luigi Cesari \& C" [7]. Із цим же хореографом (Джованні Понья) Р. Бонічолі створив ще один балет «Час», який виконувався 3 січня 1891 р. в Мілані, на сцені театру «Ла Скала». "Il tempo : ballo in sette quadri : Teatro alla Scala, carnevale quaresima 1890-91 by Riccardo Bonicioli. Premiere January 3, 1891, coreografo Giovanni Pogna” [5].

Виділимо творче оточення Р. Бонічолі. Це, наприклад, хореограф Джованні Понья (1840-1894 рр.). Він був сином сценографа Трієстського міського театру. 3 раннього дитинства він цілком присвятив себе театру і переїхав до Мілана, де відвідував мистецькі кола. Потім він працював хореографом у Трієсті та Мілані, а також в Америці, де зробив величезне багатство, яке втратив завдяки розкішній обстановці своїх театральних проєктів. Зрештою, він працював хореографом та майстром балету в міланському театрі «Ла Скала». Здійснив постановку таких балетів: «Кола ді Ріенці» композитора Е. Бернарді (1872 р.); «Етторе Фієрамоска» (1878 р.); «Ганнібал» композитора Р. Маренко (1887 p.); "Il Saltimbanco" («Акробат», 1888 р.) та “Il Тетро” («Час», 1891 р.) - обидва на музику композитора Р. Бонічолі [11].

Італійський драматург, лібретист, поет і перекладач Фердінандо Фонтана (1850-1919 рр.) був автором лібрето балету «Час». Найбільш відомий нам як автор лібрето опер Дж. Пуччіні «Вілліси» (прем’єра в 1884 р.) та «Едгар» (прем’єра в 1889 р.). У Мілані Фердінандо Фонтана належав до художньої групи Scapigliatura (літературнмй рух, який, породжений викликом традиціям, тримав інтереси відкритими для політики, критики, науки, а також мистецтва та музики). "Il tempo, dance, music by Riccardo Bonicioli (3 January 1891)" [5]. 
Подальший розвиток подій приводить нас до Аргентини. Ще одну згадку про творчість Р. Бонічолі знаходимо у книзі «Історія аргентинської опери». Її автор Енцо Валенті Ферро (1911-2009 рр.) - аргентинський музикознавець, есеїст і музичний критик, який відповідав за театр Колона, а також був директором Teatro Argentino de La Plata, пише, що Рікардо Бонічолі народився в Італії, був дуже відомим диригентом і композитором у Буенос-Айресі. Написав двоактну оперу «Хуан де Гарай», прем'єра якої відбулася в БуеносАйресі в 1900 p. "Ricardo Bonicioli was born in Italy, and was a well-known orchestra director and composer in Buenos Aires. He composed the opera Juan de Garay, a melodramatic sketch in two acts” [6]. Додамо, що на цей час Р. Бонічолі проживав в Аргентині.

Наприкінці XIX ст. ситуація з постановкою опер в Аргентині була схожа $з$ розвитком музичного мистецтва в інших країнах, де активну участь у пропаганді свого мистецтва брали італійці. Важливою подією стало створення в 1900 р. італійським композитором Ферруччо Каттелані першого стабільного оркестру Асоціації оркестрів Буенос-Айреса.

Ферруччо Каттелані (1867-1932 рр.) у 1897 р. оселився назавжди в Буенос-Айресі. До цього він виступав у країні як скрипаль та диригент. На чолі Оркестрового товариства Буенос-Айреса й Аргентинського товариства камерної та симфонічної музики він відкрив можливість слухачам цих широт дізнатися про величезний репертуар, який тут цілковито ігнорували.

У книзі «Баски в мистецтві» наводиться список опер, постановка яких була здійснена в Буенос-Айресі на початку XX ст. Це «Атауальпа» Ф. Каттелані, «Іль Сегрето» іспанського композитора Едуардо Торренса Боке та «Хуан де Гарай» Рікардо Бонічолі, також мешканця Буенос-Айреса. «Атауальпа» виконувалася 10 березня 1900 р. в театрі Сан Мартин. "Il Segreto" та "Juan de Garay" були виконані 11 жовтня 1900 р. в Теаtro Politeama Argentino. Щодо опери Р. Бонічолі зазначено: «Це єдиний ліричний вислів про персонажа басків, який відбувається в Аргентині, розповідає драму смерті генерала басків Хуана де Гарая» [8].

Висновки. Виявлено невідомі раніше відомості з біографії Рікардо Бонічолі, який два роки очолював італійську оперу антрепризи I. Черепеннікова (1887-1889 pp.). Рікардо Бонічолі 
помітно підняв рівень виконавської майстерності місцевого оперного оркестру і хорів. Репертуар збагатився першою постановкою в Одесі опери Р. Вагнера «Лоенгрін». Репертуар поповнився операми Дж. Россіні, Г. Доніцетті, Дж. Верді, Дж. Мейєрбера, Ш. Гуно, А. Понк'єллі, А. Бойто тощо. Після виконання камерних творів диригента, у яких брав участь Микола Лисенко, зазначалося, що Р. Бонічолі належить до нового напряму інструментальних композиторів Італії.

Виявлено також творче оточення митця в часи створення музики до трьох балетів, які були поставлені в Італії, а також його внесок у розвиток музичної історії Греції й Аргентини як автора опер про історичних діячів цих країн.

\section{СПИСОК ЛІТЕРАТУРИ}

1. 18 февраля «Лоэнгрин» Р. Вагнера. Впервые в Одессе. Одесский вестник. 1889. № 47, 18 февраля. С. 4.

2. Bonicioli Ricardo. URL: https://operone.de/komponist/bonicioli.html.

3. Bonicioli, Ricardo. URL: http://worldcat.org/identities/lccn-no $2004085897 /$.

4. Fontana Ferdinando. URL: https://en.wikipedia.org/wiki/Ferdinando_Fontana.

5. Fontana Ferdinando. Il tempo (The time). Ballet. Music : Riccardo Bonicioli. Premiere January 3, 1891. URL: https://de.zxc.wiki/wiki/Ferdinando_Fontana.

6. Ferro Enzo Valenti. Historia de la opera argentina. Buenos Aires, Argentina : Ediciones de Arte Gaglianone, 1997. 314 p. URL: https:// searchworks.stanford.edu/view/13827046.

7. Il saltimbanco. URL: https://www.libreriaemporium.com/ shop/il-saltimbanco-ballo-semiserio-pogna-boniccioli-teatro-dal-verme-1888-libretto/.

8. Los vascos en el Arte by EDER Editorial - issuu. URL: https:// issuu.com/editorialeder/docs/13._los_vascos_en_el_arte.

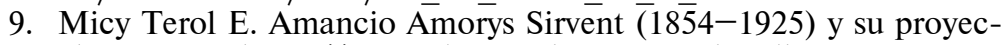
ciyn en la ... URL: https://www.tdx.cat > bitstream > handle.

10. Nadya : ballo grande in sette parti ed otto quadri : rappresentato sulle scene del Teatro dal Verme la stagione d'autunno 1881. URL: https://www.worldcat.org/title/nadya-ballo-grande-in-sette-parti-ed-otto-quadri-rappresentato-sulle-scene-del-teatro-dal-verme-la-stagione-dautunno-1881/oclc/644441818\#borrow.

11. Poselli F. Pogna, Giovanni (1840-1894), Choreograph Österreichisches Biographisches Lexikon. URL: https://www.biographien.ac.at/ oebl/oebl_P/Pogna_Giovanni_1840_1894.xml.

12. Romanou Ek katerini. Italian musicians in Greece during the nineteenth century. Musicology. 2003. № 3. P. 43-55. URL: www.doiserbia.nb.rs/ img/doi.1450-9814/2003/1450-98140303043R.pdf. 
13. Бемоль (Кузьминский И.М.). Итальянская опера. Одесский вестник. 1888. № 1, 1 января. С. 3.

14. Бемоль (Кузьминский И.М.). Музыкальная хроника. Одесский вестник. 1888. № 27, 29 января. С. 1. Маркос.

15. Боцарис Маркос. URL: https://ru.wikipedia.org/wiki/Боцарис,

16. Варварцев М. Італійці в Україні (XIX) ст. : біографічний словник діячів культури. Київ, 1994. 195 с. С. 36-37.

17. Итальянская опера. Новороссийский телеграф. 1887. 18 декабря. С. 3.

18. Т-ъ П. Городской театр. Одесский вестник. 1888. № 316, 24 ноября. С. 2.

19. Сведения о составе итальянской оперной труппы. Одесский вестник. 1887. № 234, 1 сентября. С. 3.

20. Скорульська Р., Чуєва М. Микола Лисенко. Дні і роки / Р. Скорульська. Київ : Муз. Україна, 2015. 744 с. С. 354.

21. Чепель А. Как звучит древнегреческая музыка. URL: https:// arz.mas.academy/mag/358-music.

\section{REFERENCES}

1. February 18 "Lohengrin" by R. Wagner. For the first time in Odessa (1889). Odesskiy vestnik [in Russian].

2. Bonicioli Ricardo. URL: https://operone.de/komponist/bonicioli. html [auf Deutsch].

3. Bonicioli, Ricardo. URL: http://worldcat.org/identities/lccn-no 2004085897/ [in English].

4. Fontana Ferdinando. https://en.wikipedia.org/wiki/Ferdinando_ Fontana [in English].

5. Fontana Ferdinando. Il tempo (The time). Ballet. Music: Riccardo Bonicioli. Premiere January 3, 1891. URL: https://de.zxc.wiki/wiki/ Ferdinando_Fontana [in English].

6. Ferro Enzo Valenti. Historia de la opera argentina : Buenos Aires, Argentina, Ediciones de Arte Gaglianone, (C1997. Physical description. 314 pages : illustrations, portraits. URL: https://searchworks.stanford.edu/ view/13827046 [in Spain].

7. Il saltimbanco. URL: https://www.libreriaemporium.com/shop/ilsaltimbanco-ballo-semiserio-pogna-boniccioli-teatro-dal-verme-1888libretto/ [in Italien].

8. Los vascos en el Arte by EDER Editorial - issuu. URL: https:// issuu.com/editorialeder/docs/13._los_vascos_en_el_arte [in Spain].

9. Micy Terol E. Amancio Amorys Sirvent $(1 \overline{85} \overline{4}-1925)$ y su proyecciyn en la ... URL: https://www.tdx.cat > bitstream > handle [in Spain].

10. Nadya : ballo grande in sette parti ed otto quadri : rappresentato sulle scene del Teatro dal Verme la stagione d'autunno 1881. URL: https://www.worldcat.org/title/nadya-ballo-grande-in-sette-parti-edotto-quadri-rappresentato-sulle-scene-del-teatro-dal-verme-la-stagionedautunno-1881/oclc/644441818\#borrow [in Italien]. 
11. Poselli F. Pogna, Giovanni (1840-1894), Choreograph Österreichisches Biographisches Lexikon. URL: https://www.biographien.ac.at/ oebl/oebl_P/Pogna_Giovanni_1840_1894.xml [auf Deutsch].

12. Romanou Ekaterini. Italian musicians in Greece during the nineteenth century. Musicology. 2003. № 3. P. 43-55. URL: www.doiserbia.nb.rs/img/doi.1450-9814/2003/1450-98140303043R.pdf [in English].

13. Bemol (I.M. Kuzminsky). Italian Opera / Bemol (I.M. Kuzminsky) (1888) Odessriy vestnik [in Russian].

14. Bemol (I.M. Kuzminsky). Musical Chronicle / Bemol (I.M. Kuzminsky) (1888) Odessa Bulletin [in Russian].

15. Bozzaris Marcos. URL: https://ru.wikipedia.org/wiki/Боцарис, Маркос [in Russian].

16. Varvartsev M.M. (1994). Italians in Ukraine (XIX) century. biogr. dictionary of cultural figures. Kiev, 1994 [in Ukraine].

17. Italian Opera (1887). Novorossiyskiy Telegraph [in Russian].

18. P. T-b. City Theater (1888). Odesskiy vestnik [in Russian].

19. Information about the composition of the Italian opera troupe (1887) Odesskiy vestnik [in Russian].

20. Skorulska R. Mykola Lysenko. Days and Rocky (2015). Kiev : Muz. Ukraine, 2015 [in Ukraine].

21. Chepel A. How does ancient Greek music sound. URL: https://arz.mas.academy/mag/358-music [in Russian]. 